\title{
Eviction process in Nigeria: the need for meaningful engagement
}

\section{Aisosa Isokpan \& Ebenezer Durojaye}

To cite this article: Aisosa Isokpan \& Ebenezer Durojaye (2018) Eviction process in Nigeria: the need for meaningful engagement, Commonwealth Law Bulletin, 44:1, 3-25, DOI: 10.1080/03050718.2018.1557063

To link to this article: https://doi.org/10.1080/03050718.2018.1557063

曲 Published online: 08 Jan 2019.

Submit your article to this journal $\pi$

III Article views: 47

Q View related articles $₫$

View Crossmark data $\asymp$ 


\title{
Eviction process in Nigeria: the need for meaningful engagement
}

\author{
Aisosa Isokpan $^{\mathrm{a} *}$ and Ebenezer Durojaye ${ }^{\mathrm{b}}$ \\ ${ }^{a}$ Faculty of Law, University of the Western Cape, Cape Town, South Africa; \\ ${ }^{b}$ Socio-economic Rights Project, Dullah Omar Institute, Faculty of Law, University of \\ the Western Cape, Cape Town, South Africa
}

\begin{abstract}
The important process of meaningful engagement with persons affected by eviction has been greatly under-utilised in Nigeria and this leaves the victims in a dire situation as their yearnings are hardly met. Having regard to the jurisprudence of the South African Constitutional Court on meaningful engagement, a critical evaluation of the case of Badia East eviction in Lagos, Nigeria is considered highlighting the flaws in the engagement process adopted. It is shown that the process of meaningful engagement with affected persons before an eviction occurs has the capacity to mitigate the human rights abuses that could arise from the process.
\end{abstract}

\section{Introduction}

The adoption of the African Charter for Popular Participation in Development and Transformation was prompted by the deterioration of economic and social conditions in African countries partly due to the lack of appreciation of the role of popular participation in the development process. ${ }^{1}$ It was observed that at the heart of Africa's progress is a human-centred development that ensures the overall well-being of the people through sustained improvement in their living standards and the full and effective participation of the people in charting their development policies, programmes and processes and contributing to its realization. ${ }^{2}$ Achieving this requires the government to create the necessary conditions to facilitate effective popular participation in societal and economic life by opening up political process to accommodate freedom of opinions, tolerate differences, accept consensus on

\footnotetext{
*Corresponding author. Email: 3508033@ myuwc.ac.za

${ }^{1}$ African Charter for Popular Participation in Development and Transformation adopted by acclamation by the participants at the International Conference on Popular Participation in the Recovery and Development Process in Africa Arusha in February 1990. The Charter largely contains recommendations on the role of governments in enhancing popular participation. The Charter also does not include sanctions for failure of governments to comply with the recommendations made in the charter. As such it largely falls in the category of soft law and not a legally binding instrument. This status does not however make it of less importance as a tool for ensuring State policies are in tandem with the will of the citizens. See Kufor KO 'The African Charter for Popular Participation in Development and Transformation: A Critical Review' (2000) 18(1) Netherlands Quarterly of Human Rights 7-22.

${ }^{2}$ Ibid 8 .
} 
issues in order to ensure the effective participation of the people and their associations. Popular participation cannot be achieved if the government fails to yield space to the people. An instance in which such a space can be created is in the process of consulting and meaningfully engaging with citizens to discuss issues that affect their wellbeing.

Indeed, there are inevitable needs for the redevelopment of certain areas in growing cities and the acquisition of land for public use and infrastructure which could result in the displacement of people. It is the way in which such projects are conceived, developed and implemented that is problematic. Very often they are carried out with little or no consultation with those affected and limited consideration of their needs or attempts made to develop solutions which minimize the scale of the eviction and the disruption caused. ${ }^{3}$

Most persons affected by evictions in Nigeria are the poor and the marginalised and their situation is worse off as they are rendered homeless and vulnerable to other human rights abuses. Worse still, some of these persons are left for years without the legally required compensation for the compulsory acquisition of their properties or an alternative settlement. This has terrible consequences for the survival of those affected as they are driven deeper into poverty as a result of being unable to access means of livelihood, education and other socio-economic services. In this situation, economic and social factors weigh heavily against them and they are denied access to justice or other effective remedies. This is largely because eviction planning does not take the interest of affected persons into consideration which can only be made possible through a meaningful engagement process.

This article seeks to address the human rights implications of evictions in Nigeria through the process of meaningful engagement. In doing this, the article will consider pertinent issues such as the international framework protecting the rights of persons affected by eviction; how a meaningful engagement process cushions the human rights abuses inherent in evictions; the situation of victims of eviction in Nigeria and how the government has handled the process over time. Through a review of the flawed engagement process adopted in the Badia East eviction in Nigeria, it will be shown that most of the problems that arise in the aftermath of an eviction could be resolved to a large extent if an opportunity is given to the affected persons through meaningful engagement to discuss issues regarding alternative settlement, adequacy of and time frame for compensation, the procedure and time frame of relocation, as well as available remedies. Such engagement will give room for all interests to be represented as well as those ordinarily marginalised groups such as women, children, disabled, and elderly amongst others.

The next section looks at the legal framework for protecting persons affected by evictions. Section 3 considers the need for meaningful engagement as a good practice as will be shown from the jurisprudence of the South African Constitutional Court. Section 4 takes a leap into the situation of forced evictions in Nigeria emphasising the lack of engagement with victims. Section 5 takes a

${ }^{3}$ Office of the United Nations High Commissioner for Human Rights 'The Right to Adequate Housing' Fact Sheet No 21/Rev.1 (UNHCR 2009) 7. 
critical look at the process of engagement adopted in the Badia East eviction in Lagos state highlighting the flaws in the engagement process. Thereafter, some concluding remarks and recommendations are made.

\section{Legal framework for the protection against forced eviction}

The protection from forced eviction is inherent in the right to adequate housing recognised in Article 11 of the International Covenant on Economic, Social and Cultural Rights (ICESCR) and other international human rights instruments. ${ }^{4}$ The right which is derived from the broad right to an adequate standard of living ${ }^{5}$ is of central importance for the enjoyment of all economic, social and cultural rights 6 as it serves as a protection, a place to rest and raise a family. The right to adequate housing cannot be viewed in isolation as it is linked to other rights such as nondiscrimination, privacy, freedom of expression and association, participation in public decision making, health, work, education, and personal security. ${ }^{7}$ The South African Constitutional Court in Government of the Republic of South Africa v. Grootboom viewed the right to housing as inherent in the right to human dignity and as such a "society must seek to ensure that the basic necessities of life are provided for all if it is to be a society based on human dignity, freedom, and equality'. 8

The Committee on Economic, Social and Cultural Rights (CESCR) has noted that essential to the right to adequate housing is the legal security of tenure which could be in form of public or private rental accommodation, cooperative housing, lease, owner-occupation, emergency housing and informal settlements, including the occupation of land or property. ${ }^{9}$ However the nature of the tenure, all persons should possess a degree of security of tenure which guarantees legal protection against forced eviction, harassment and other threats. ${ }^{10}$ The CESCR has defined forced eviction to mean 'the permanent or temporary removal against their will of individuals, families and/or communities from the homes and/or land which they occupy, without the provision of, and access to, appropriate forms of legal or other protection'. ${ }^{11}$ The protection of people against forced evictions is linked to

\footnotetext{
${ }^{4}$ Universal Declaration of Human Rights, 1948, Art25; International Convention on the Suppression and Punishment of the Crime of Apartheid, 1973, Art 11(b) and (d); International Convention on the Elimination of All Forms of Discrimination against Women, 1979, Art 14(2)(h); International Convention on the Rights of the Child 1989, Art 27(3).

${ }^{5}$ In Article 11(1) of the ICESCR, this right includes the right to food and clothing.

${ }^{6}$ Committee on Economic, Social and Cultural Rights (CESCR) General Comment No. 4 'Right to adequate housing' $13^{\text {th }}$ December 1991 para 1; Government of the Republic of South Africa v. Grootboom 2001 (1) SA 46 (CC) para 24.

${ }^{7}$ (CESCR) General Comment No. 4 para 9.

${ }^{8}$ Ibid para 44.

${ }^{9}$ General comment 4 para $8(\mathrm{a})$.

${ }^{10}$ Ibid; United Nations Habitat Agenda A/CONF.165/13 14 June 1996 para 61(b).

${ }^{11}$ Committee on Economic, Social and Cultural Rights General Comment No. 7 'The right to adequate housing: Forced eviction' 1997 para 3.
} 
the security of tenure, which is an essential element of the right to adequate housing. $^{12}$

Forced evictions are carried out in a variety of circumstances and for a variety of reasons, for instance, to make way for development projects, urban renewal or city beautification, or to create space for international events such as the eviction of some residents in Cape Town ahead of the World Cup in South Africa in 2010. ${ }^{13}$ Regardless of the cause, forced eviction is considered a violation of human rights, especially the right to adequate housing as it tends to be violent and disproportionately affect the poor, who often suffer further human rights violations as a result. ${ }^{14}$ Evictions for development purposes may be justified only if they take place in accordance with the relevant principles of international law. ${ }^{15}$ When evictions are carried out as a last resort, those affected must be afforded an opportunity for genuine consultation; adequate and reasonable notice; information on the proposed evictions including the alternative purpose for which the land or housing is to be used must be made available in reasonable time to all those affected; payment of appropriate compensation for properties affected by the eviction as well as access to effective legal remedies. ${ }^{16}$ Where those affected are unable to provide for themselves, the State party must take all appropriate measures, to the maximum of its available resources, to ensure that adequate alternative housing, resettlement or access to productive land, as the case may be, is available. ${ }^{17}$ These protections should apply to all persons affected irrespective of the status of tenure. In essence, evictions should not result in individuals becoming homeless or vulnerable to further human rights violations. ${ }^{18}$

On the need for consultation or meaningful engagement, which is the crux of this paper, States are required prior to carrying out any evictions, and particularly those involving large groups, to ensure that 'all feasible alternatives are explored

\footnotetext{
${ }^{12}$ UNHCR (n 3$) 4$.

${ }^{13}$ Raghavan $\mathrm{S}$ 'In preparation for world cup, the poor in Cape Town are being relocated' Friday June 112010 Washington Post http://www.washingtonpost.com/wpdyn/content/article/2010/06/10/AR2010061002060.html > accessed 6 February 2017.

${ }^{14}$ UNHCR (n 3) 5. According to the CESCR, appropriate procedural protections are relevant for all human rights particularly in the case of forced evictions as it has an implication for rights recognised in both the ICCPR as well as the ICESCR. While manifestly breaching the rights enshrined in the ICESCR, the practice of forced evictions may result in the violation of other civil and political rights such as the right to life, security of the person, the right to non-interference with privacy, family and the home as well as the peaceful enjoyment of possessions (General comment No. 7 (n 11) para 4,7$)$.

${ }^{15}$ CESCR General Comment No.7 (n 11) para 14.

${ }^{16}$ ibid para 15 .

${ }^{17}$ Ibid para 16. The procedural protection that must be applied in cases of forced eviction include an opportunity for genuine consultation with those affected; adequate and reasonable notice; information on the proposed evictions to be made available in reasonable time; government officials or their representatives to be present during an eviction; all persons carrying out the eviction to be properly identified; evictions not to take place in particularly bad weather or at night unless the affected persons consent otherwise; provision of legal remedies; and provision, where possible, of legal aid to persons who are in need of it to seek redress from the courts.

18 ibid para 16.
} 
in consultation with the affected persons, with a view to avoiding, or at least minimizing, the need to use force'. ${ }^{19}$ Also, the United Nations Basic Principles and Guidelines on Development-Based Evictions and Displacement requires that 'all potentially affected groups and persons, including women, indigenous peoples and persons with disabilities, as well as others working on behalf of the affected, have the right to relevant information, full consultation and participation throughout the entire process and to propose alternatives that authorities should duly consider'. ${ }^{20}$ It also requires that 'during planning processes, opportunities for dialogue and consultation must be extended effectively to the full spectrum of affected persons, including women and vulnerable and marginalized groups'. ${ }^{21}$ The need for consultation has equally been stressed by the United Nations SubCommission on the Prevention of Discrimination and Protection of Minorities. ${ }^{22}$

The African Commission in the case of Socio Economic Rights Action Centre (SERAC) and another $v$ Nigeria $^{23}$ noted that 'although the right to housing or shelter is not explicitly provided for under the African Charter, the corollary of the combination of the provisions protecting the right to enjoy the best attainable state of mental and physical health, cited under article 16, the right to property, and the protection accorded to the family forbids the wanton destruction of shelter because when housing is destroyed, property, health and family life are adversely affected'. ${ }^{24}$ Also, the Principles and Guidelines on the Implementation of Economic, Social and Cultural Rights in the African Charter on Human and Peoples Rights (Nairobi Principles) ${ }^{25}$ obligate States Parties to ensure that where planning and development processes include evictions, all those likely to be affected should be actively consulted. In all, eviction must include appropriate individual notice to all potentially affected persons; effective dissemination by the authorities of relevant information in advance; a reasonable time period for public review of, comment on, or objection to the proposed plan; opportunities and efforts to facilitate the provision of legal, technical and other advice to affected persons about their rights and options; and holding of public hearings that provide affected persons and their advocates with opportunities to challenge the eviction decision or to present alternative proposals and to articulate their demands. ${ }^{26}$

The prohibition of forced eviction does not apply to evictions carried out in accordance with the law and in conformity with the provisions of international human rights standards. As such, if a government has given adequate notice,

\footnotetext{
${ }^{19}$ ibid para 13 and 15.

${ }^{20}$ United Nations Basic Principles and Guidelines on Development-Based Evictions and Displacement (2006) UN Doc. A/HRC/4/18 para 38.

${ }^{21}$ Ibid para 39.

${ }^{22}$ United Nations Sub-Commission on Prevention of Discrimination and Protection of Minorities Resolution 1997/6 on forced evictions para 3.

${ }^{23}$ SERAC v Nigeria (2001) AHRLR 60.

${ }^{24}$ Ibid para 60.

${ }^{25}$ Principles and Guidelines on the Implementation of Economic, Social and Cultural Rights in the African Charter on Human and Peoples Rights was adopted by the African Commission on Human and Peoples' Rights in November 2010 at its 48th session.

${ }^{26}$ ibid 42.
} 
genuinely consulted with affected persons and explored all feasible alternatives to eviction, provided adequate remedies, adequate alternative housing and compensation, the use of appropriate and reasonable force to carry out the eviction would not amount to forced eviction. ${ }^{27}$

\section{Meaningful engagement}

Participation has been defined as the fundamental right of people to be involved in the determination of the decisions which affect their lives at all levels and at all times. ${ }^{28}$ Chenwi has noted that it is possible to participate without being engaged except when it is full, effective and active. ${ }^{29}$ She thus defines meaningful engagement as occurring 'when communities or individuals and the government talk and listen to each other, in order to achieve certain objectives. ${ }^{30}$ It requires the state when it develops policies and programmes and in the provision of services, to effectively seek and consider the views of beneficiaries, thus making them 'active stakeholders rather than just passive recipients of socio-economic goods and services'. ${ }^{31}$ A meaningful engagement process is one which gives all affected persons the opportunity to participate either directly or indirectly through their representatives. This process thus affords impoverished groups meaningful tools with which to challenge the barriers that undermine the full and equal participation in the society thereby increasing the responsiveness of social policies to those affected by it. ${ }^{32}$

Meaningful engagement is a remarkable development in the South African Constitutional Court's approach to the enforcement of socio-economic rights as an effective tool in decision-making. Before the development by the courts, the legal basis for meaningful engagement already existed in the laws of South Africa. ${ }^{33}$ Despite the broad provision for socio-economic rights in the South African Constitution, the realisation was constrained partly due to the absence of public participation, especially at the local level as government officials made decisions unilaterally without involving the local people. ${ }^{34}$ Among the factors associated with the huge service delivery challenge was the weak community participation

\footnotetext{
${ }^{27}$ Amnesty International 'Ending Forced Evictions in Law and Practice: A Thematic Submission to the United Nations Committee on Economic, Social and Cultural Rights ACT35/006/2013 (May 2013) https://www.amnesty.org/en/documents/act35/006/2013/ en/19.

${ }^{28}$ African Charter for Popular Participation in Development and Transformation para 10 .

${ }^{29}$ Lilian Chenwi, 'Meaningful Engagement' in the Realisation of Socio-economic Rights: The South African Experience’ (2011) 26 South African Public Law 130.

${ }^{30}$ Ibid.

${ }^{31}$ Ibid.

${ }^{32}$ Sandra Liebenberg, 'Participatory Approaches to Socio-economic Rights Adjudication: Tentative Lessons for South African Evictions Law' (2014) Nordic Journal of Human Rights 315.

${ }^{33}$ The Constitution of the Republic of South Africa 1996 section 33, 152(1) (a) and (e), 195 (1) (e) and (g); Promotion of Administrative Justice Act (Act 3 of 2000) section 3 and 4; Housing Act 107 of 1997 section 2(1) (a)(b) Prevention of Illegal Eviction from and Unlawful Occupation of Land Act 19 of 1998 section 7.

${ }^{34}$ Chenwi (n 29) 128.
} 
and the absence of genuine consultation, which resulted in a top-down approach to decision-making. ${ }^{35}$ Meaningful engagement in the South African Constitutional Courts jurisprudence has its roots in the decision in Port Elizabeth Municipality $v$ Various Occupiers. ${ }^{36}$ The significance of participation, according to the Court, is grounded in respect for the human dignity of occupiers. ${ }^{37}$

The Court also noted that 'one potentially dignified and effective mode of achieving sustainable reconciliations of the different interests is to encourage and require the parties to engage with each other in a pro-active and honest endeavour to find mutually acceptable solutions. Wherever possible, respectful face-to-face engagement or mediation through a third party should replace arms-length combat by intransigent opponents'. ${ }^{38}$ Meaningful engagement thus gives vulnerable groups faced with the threat of eviction from the roof over their heads, a voice in the proceedings that could lead to such a decision being taken. ${ }^{39}$

Sturm has noted that participation should focus on individuals, groups or organisation that may be affected by the case. ${ }^{40}$ Meaningful engagement is both individual and collective, meaning that it is not enough for government to simply consult with committees claiming to represent communities or to just consult individuals and households but must do both. In other words, the state must respond in a reasonable way to the contradictions and tensions that may arise between groups and individuals in a community when a socio-economic policy is put into effect. ${ }^{41}$ The nature of participation required for an engagement to be meaningful is the forging of a partnership between the government and the people participating to enable them rise above the often misconceived conception of them as being helpless and at the mercy of government. ${ }^{42}$

There was a broad approach to meaningful engagement in the case of Occupiers of 51 Olivia Road, Berea Township and 197 Main Street, Johannesburg v. City of Johannesburg and Others. ${ }^{43}$ In that case, the city of

\footnotetext{
${ }^{35}$ Department of Cooperative Governance and Traditional Affairs State of Local Government in South Africa Working Document COGTA (2009) 72.

${ }^{36}$ Port Elizabeth Municipality v Various Occupiers 2005 (1) SA 217 (CC).

${ }^{37}$ Ibid para 41. Justice Albie Sachs in Residents of Joe Slovo Community $v$ Thubelisha Homes \& Others 2010 (3) SA 454 (CC) reasoned along this line and equally noted that officials seeking eviction should be encouraged not to rely on concepts of faceless and anonymous squatters automatically to be regarded as obstinate and obnoxious social nuisances. Justice and equity require that everyone be treated as an individual bearer of rights entitled to respect for his or her dignity para 405-406.

${ }^{38}$ Port Elizabeth Municipality v Various Occupiers para 39.

${ }^{39}$ Liebenberg (n 32) 327.

${ }^{40}$ Susan Sturm, 'A Normative Theory of Public Law Remedies' (1991) 79 George Town Law Journal 1410.

${ }^{41}$ Lilian Chenwi and Kate Tissington, Engaging Meaningfully with Government on Socio-economic Rights: A Focus on the Right to Housing (Community Law Centre 2010) 9.

${ }^{42}$ Gustav Muller, 'Conceptualising "Meaningful Engagement" as a Deliberative Democratic Partnership' in Sandra Liebenberg and Geo Quinot Law and Poverty Perspectives from South Africa and Beyond (Juta 2012) 314.

${ }^{43}$ Occupiers of 51 Olivia Road, Berea Township and 197 Main Street, Johannesburg v. City of Johannesburg and Others 2008 (3) SA 208 (CC).
} 
Johannesburg had issued notices under the National Building Regulations and Building Standards Act 103 of 1977 requiring thousands of occupiers of so-called bad buildings in the inner city to vacate the buildings. The applicants also challenged the city's failure to formulate a housing plan for persons affected by the eviction notice issued by the respondents. Prior to handing down its final judgment, the court issued an interim order requiring the parties to meaningfully engage with each other as soon as it is possible for them to do so. This is in an effort to resolve the differences and difficulties aired in the application. ${ }^{44}$

The post-engagement agreement made explicit provisions for measures aimed at rendering both properties safer and more habitable in the interim. ${ }^{45}$ The agreement also obliged the city to provide all occupiers with alternative accommodation in certain identified buildings. It defined with reasonable precision the nature and standard of the accommodation to be provided and determined the way in which the rent in respect of the accommodation will be calculated. ${ }^{46}$ The engagement agreement was endorsed and made an order of the court.

In this case, the Constitutional Court held that meaningful engagement is 'a two-way process in which the City and those about to become homeless would talk to each other meaningfully in order to achieve certain objectives'. Meaningful engagement requires the state to effectively seek and consider the views of beneficiaries when it develops policies and programmes in the fulfilment of socio-economic rights. ${ }^{47}$ Thus, it is not meaningful engagement where the government persuades the community to accept a decision it has already made on the ground that it is in their best interest.

The Court further elaborated on the requirements to make an engagement process meaningful. First, the need for competent sensitive council workers skilled in engagement is a necessary structure for meaningful engagement. ${ }^{48}$ Second, the process will work only if both sides to the engagement act reasonably and in good faith. Those who might be rendered homeless should not make 'non-negotiable and unreasonable demands'. They 'are not and must not be regarded as a disempowered mass' but rather be encouraged to be 'pro-active and not purely defensive'. ${ }^{49}$ Third, those facing eviction may be as vulnerable as not to understand the need for the engagement process in which case they might likely back out. In such a situation, government cannot proceed without engagement unless it has made reasonable efforts to keep them involved.$^{50}$ Fourth, civil societies that support the people's claim should facilitate the process in every way. ${ }^{51}$ Fifth, the court noting the counter-productive nature of secrecy in engagement stated that the process should be open and a completely accurate record of the process should

\footnotetext{
${ }^{44}$ Ibid para 5 .

45 ibid para 25.

${ }^{46}$ ibid para 26.

${ }^{47}$ Chenwi (n 29) 129.

${ }^{48}$ Occupiers of 51 Olivia Road, Berea Township and 197 Main Street, Johannesburg $v$. City of Johannesburg and Others para 19.

${ }^{49}$ ibid para 20.

${ }^{50}$ ibid para 15.

${ }^{51}$ ibid para 20.
} 
be kept. ${ }^{52}$ The court also noted that the process of engagement should take place prior to the commencement of litigation unless it is not possible or reasonable to do so owing to the urgency of the situation or other compelling reason. ${ }^{53}$ The meaningful engagement principle has been further applied in other cases before the constitutional court. ${ }^{54}$

The Olivia Road case demonstrates that through meaningful engagement, competing interests can be effectively resolved and to a large extent a win-win situation can be achieved. In circumstances where a powerful bargaining power such as the government is involved, the poor and vulnerable people are not left without a remedy as the engagement process give them the opportunities to air their concerns and have those concerns considered in the final outcome of the process. Also, meaningful engagement can lessen the burden on the courts with respect to matters arising out of eviction disputes as they would have been resolved in the process. Liebenberg has argued that the application of meaningful engagement has:

Signalled an affirmation by the Court that the housing rights protected in section 26 of the Constitution, in addition to conferring substantive benefits, entitle unlawful occupiers to participate in the process of finding a just solution to what often appears as the intractable conflict between their housing rights and the property rights of landowners. ${ }^{55}$

While the Constitutional Court's application of the notion of meaningful engagement has been hailed by scholars, Liebenberg has noted that the Court has not been consistent with the application of this principle. ${ }^{56}$ She cited the Joe Slovo case as an example of where the Court departed from its earlier position on this principle. Whereas the Court had noted in Olivia Road and Abahlali base'Mjondolo cases that meaningful engagement is a condition precedent to

\footnotetext{
52 ibid para 21.

${ }^{53}$ ibid para 30.

${ }^{54}$ In Abahlali base'Mjondolo Movement of South Africa $v$ Premier of the Province of KwaZulu Natal 2010 (2) BCLR 99 (CC) the court held that proper engagement would take into proper consideration the wishes of the people who are to be evicted, whether the areas where they live may be upgraded in situ and whether there will be alternative accommodation, the manner and timeframe of the eviction (para 114). Also, in Schubart Park Residents Association v City of Tshwane Metropolitan Municipality 2013(1) SA 323 (CC), the applicants were forcibly removed from the buildings they were occupying on grounds of alleged health and safety concerns by national and municipal law enforcement and fire brigade leaving between 3000 and 5000 persons homeless or in temporary shelters. Attempt by the legal representatives of the applicants to engage with the city officials in an effort to come to an agreement on various matters including temporary accommodation yielded nothing. The Constitutional court relying on PE Municipality and Olivia Road held the exercise of these often competing rights and interests can best be resolved by engagement between the parties.

${ }^{55}$ Sandra Liebenberg, "Engaging the Paradoxes of the Universal and Particular in Human Rights Adjudication: The Possibilities and Pitfalls of 'meaningful engagement" (2012) African Human Rights Law Journal 14.

56 ibid 26.
} 
eviction process, the Court in Joe Slovo permitted an eviction process despite lack of evidence to show that the people affected were not properly consulted. This is a departure from the Court's earlier stance on the issue. Nonetheless, meaningful engagement remains a viable tool for achieving reconciliation and protecting the rights of disadvantaged groups during eviction.

\section{Compulsory acquisition of properties in Nigeria}

Compulsory acquisition has been defined as 'the power of government to acquire private rights in land without the willing consent of its owner or occupant in order to benefit society ${ }^{57}$ It is a necessary tool for governments in ensuring the availability of land for the development of essential infrastructure for public benefit. ${ }^{58}$ However, the establishment of an efficient and fair legal and institutional framework for exercising this power remains a challenge in many countries including Nigeria. ${ }^{59}$ The reason is that in the compulsory acquisition process, the desire for efficiency and speed by the acquiring authority on the one hand and the objectives of safeguarding the interests of affected people co-exist in a state of tension. ${ }^{60} \mathrm{It}$ is however argued that they are complementary as 'cutting corners on procedures designed to address the needs and aspirations of affected people can have severe debilitating effects on the success of the eventual investment, by creating long-standing local resentments and other negative legacies'. ${ }^{61}$

The law on compulsory acquisition of land in Nigeria is rooted in the Constitution of the Federal Republic of Nigeria 1999 (as amended) which guarantees the right of every citizen of Nigeria to acquire and own immovable property anywhere in Nigeria. Where such property is to be compulsorily acquired by the government, the Constitution provides for the prompt payment of compensation ${ }^{62}$ and such owner of the property has a right to judicial remedies for the determination of his interest in the property and the amount of compensation. ${ }^{63}$ The Land Use Act of 1978 was designed to assist the government to acquire lands by setting out the conditions for such acquisition. ${ }^{64}$ By virtue of section 28 of the Act, the

\footnotetext{
${ }^{57}$ A Otubu, 'Private Property Rights and Compulsory Acquisition Process in Nigeria: The Past, Present and Future' (2012) 2(8) Juridica 7: Food and Agriculture Organisation (FAO) Compulsory Acquisition of Land and Compensation (2008) FAO; Italy. The term compulsory acquisition has a number of connotations which include expropriation, compulsory purchase, land-take and eminent domain. Whichever term used, the result is the relinquishment of the owner or occupants rights for public interest.

${ }^{58}$ VA Akujuru, L Ruddock, 'The Determination of Compensation Payable in the Niger Delta for Compulsory Acquisition and the Need for a Sustainable Practice' (2014) 16 (2) Journal of Sustainable Development in Africa 103.

${ }^{59} \mathrm{JM}$ Lindsay, 'Compulsory Acquisition of Land and Compensation in Infrastructure Projects' (2012) 1(3) PPP Insights 1.

${ }^{60}$ ibid 8-9.

${ }^{61}$ ibid 9.

${ }^{62}$ Section 44(1) (a) CFRN 1999.

${ }^{63}$ Section 44(1)(b) CFRN 1999.

${ }^{64}$ The Act vests all lands in the state in the state governor to hold it in trust for the people. This vesting made it easier for the governor to acquire land for development
} 
governor can revoke a statutory right of occupancy for overriding public interest and notice must be given to the holder of such right. ${ }^{65}$ Upon receipt of the notice, the right of the holder shall be extinguished ${ }^{66}$ and he is compelled by law to surrender his interest in the land in favour of the government. ${ }^{67}$ Section 29 of the Act also provided for the payment of compensation upon acquisition of the land.

The expropriation of Land in Nigeria increased following the enactment of the Land Use Act resulting in the displacement of large numbers of people for the development of industry and urban areas. The acquisition process often results in untold hardship as a result of the disruption of the means of livelihood of the landowners. ${ }^{68}$ As of 2006, about 2 million people had lost their homes and land to compulsory land acquisitions. ${ }^{69}$ Over 1.2 million people have been evicted from the Port Harcourt area to allow for development of the oil and gas industries while the federal government has since 2003 evicted more than 800,000 people in the Federal Capital Territory, Abuja. $^{70}$ Most of these acquisitions were often not in compliance with the law as several issues of contention arise out of the acquisition process and have been subject of litigation overtime. These issues usually bother on whether the purpose of acquisition is for an overriding public interest, proper notice to the owner of land or delayed or inadequate compensation. ${ }^{71}$

The FAO has noted that there is a process by which the power of compulsory acquisition is exercised, and adherence to the procedures is critical if a government's exercise of this power is to be efficient, fair and legitimate. ${ }^{72}$ The

purposes as against the erstwhile customary land tenure that made acquisition difficult. See A Mendie, J Aster, B Ofem, 'Analysis of Public Lands Acquisition in Akwa Ibom State, Nigeria' (2010) 31(3) Journal of Human Ecology 197; DK Oluwamotemi, 'Land Acquisition, Compensation and Resettlement in Developing Economies: Nigeria as a Case Study' Being a paper presented at the FIG Congress 2010 on 11-16 April 2010 in Sydney, Austria 6.

${ }^{65}$ Section $28(6)$ LUA.

${ }^{66}$ Section 28 (7) LUA.

${ }^{67}$ Mendie, Aster, Ofem (n 64) 197-198.

${ }^{68}$ A Haruna, FA Ilesanmi, BD Yerima, 'Problems of Formal Land Acquisition Policies in Nigeria: The Case of Jimeta-Yola, Adamawa State, Nigeria' (2013) 3(11) Journal of Environment and Earth Science 1-2.

${ }^{69}$ USAID Nigeria-Property rights and resource governance profile' September 2010 available at http://www.usaidlandtenure.net/sites/default/files/country-profiles/fullreports/ USAID_Land_Tenure_Nigeria_Profile.pdf (accessed 7 September 2016)12

${ }^{70}$ Ibid

${ }^{71}$ Goldmark Nig Ltd \& Others v Ibafon Company Ltd \& Others (2012) LPELR-SC. 421/2001; Oviawe v I.R.P (Nig) Ltd. (1997) 3 NWLR (pt 492) 126; Dumez Nig PLC v Ademoye \& Ors (2014) LPELR - 23518 (CA); Provost of Lagos State College of Education \& Ors v Dr. Kolawole Edun \& Ors [2004] 6 NWLR (pt 870) 476-509; Dantsoho v Mohammed [2003] 6 NWLR (pt. 817) 457; Baba Iya v Sikeli [2006] 3 NWLR (pt 968) 508; N.E.W Ltd v DENAP Ltd [1997] 10 NWLR (pt 526) 481; Attorney-General of Bendel State \& 2 Ors v Aideyan (1980) 4 NWLR (pt. 188) 64; Executors of the Estate of Abacha $v$ Eke-Spiff (2003) I NWLR (pt 800) 114; Mohammed Bulama v Federal Capital Development Authority \& Anor Unreported Suit No. FCT/HC/CV/1174/13.

${ }^{72} \mathrm{FAO}$ (n 57) 15. 
Constitution as well as the Land Use Act merely provides for notice to the holder upon compulsory acquisition and also payment of compensation upon such acquisition. The giving of notice helps to protect the rights of the affected persons ${ }^{73}$ but more than that is needed for the outcome of the process to cater for their various interests. The law is silent on other necessary safeguards to ensure the rights of the affected persons are protected such as an opportunity for genuine consultation. Essential in the acquisition process is that of publicity which requires the government to notify those affected of the intended acquisition, the purpose and process, as well as important deadlines and the procedural rights of people. It also includes the holding of public meetings to provide people with an opportunity to learn more about the project, and to express their opinions and needs for compensation. ${ }^{74}$ Adherence to these principles will ensure that the affected persons are fully engaged and their voices are heard and their interest considered in the final decisions made. ${ }^{75}$

Unfortunately, this is not the case in most acquisitions in Nigeria. The valuation of compensation is done by the state without any input by the affected persons in terms of representation and or raising objections against the whole process. It has been noted that in most acquisitions in the Niger Delta are a of Nigeria, affected owners and occupants often have a weak negotiating power, experience and skills compared with the acquiring agency. ${ }^{76}$ Also, the usually poor communities involved do not have skilled valuation experts to assist in the compensation assessment process or advise them of their entitlement. Due to these constraints, they are forced into accepting what is offered under pressure. ${ }^{77}$

This article posits that even though the right to adequate housing, which includes the right to tenure security, is not a substantive right in Nigeria, it does not mean that due process cannot be followed in the compulsory acquisition of properties. The available law which is the LUA merely provides for notice to the owners and the provision of adequate compensation. Also, the law does not consider the various interests that are represented in such acquisition including tenants and squatters. These persons are expected to vacate the acquired properties but the timeframe and manner of relocation so as not to be exposed to severe hardship needs to be considered. Since the law is silent on the modalities for achieving a fair acquisition process, all these can only be resolved through a process of engagement between the acquiring authorities and the affected persons. It will provide an opportunity for such issues to be addressed and to an extent ease the burden on lessen the burden on the courts in relation to disputes that could arise from an unsatisfactory acquisition process.

\footnotetext{
${ }^{73} \mathrm{FAO}$ (n 57) 20.

${ }^{74} \mathrm{FAO}$ (n 57) 16. The FAO has suggested that the notice should be so widely dispersed as to reach all affected persons, erring on the side of over-inclusiveness. This will enable all affected owners and occupants to avail themselves of the opportunity to be heard and have their concerns acknowledged and addressed by the acquiring agency. FAO (n 57) 54.

${ }^{75}$ FAO (n 57) 21.

${ }^{76}$ Akujuru and Ruddock (n 58) 112.

${ }^{77}$ Ibid.
} 


\section{Forced evictions in slums and informal settlements in Nigeria}

It has been stressed that the increased urbanization and resultant deterioration of living conditions in urban areas is a major challenge that requires urgent and sustained efforts to address. ${ }^{78}$ The accelerated pace of rural-urban migration has led to an increase in development of slums and spreading of informal settlement in major cities in Nigeria, especially Lagos and Abuja. They are characterised by poverty, lack of land tenure, predominantly informal economy, violence, poor sanitary conditions, inadequate infrastructure, poor land use planning and they are generally unfit for human habitation as inhabitants are exposed to communicable diseases. ${ }^{79}$ These problems are due to the absence of adequate infrastructure and basic amenities to cater for the rising population and also the fact that the rapid rate of urbanisation has not been matched with a supply of adequate and affordable housing to cater for the urban poor. ${ }^{80}$

The slum dwellers are largely poor people who have migrated to the cities in search of employment and a better standard of living. As such they are mostly low-income earners without occupational skills and qualification. ${ }^{81}$ Because of their inability to access affordable land or adequate housing, they resort to living in slums with deplorable conditions, squatting or illegal occupation of unauthorised lands. ${ }^{82}$ In this situation, they have an insecure tenure and thus prone to evictions. Likewise, their views on issues relating to the use and development of land is given little or no consideration. ${ }^{83}$

In a bid to address these issues associated with the increased urbanisation, the government embarks on urban renewal plans and beautification involving the construction of wider roads and necessary infrastructure to cater for growing population. This often has negative effects on urban residents, especially slum dwellers as a result of forceful eviction leading to loss of properties and livelihood. ${ }^{84}$ By virtue of being poor, slum dwellers are a minority group, voiceless, marginalised and highly vulnerable to human rights violations, especially when they are forcefully evicted from their settlements. Slum settlers have a right to be consulted before they are evicted because they usually form a close-

\footnotetext{
${ }^{78}$ Neel M. Butala, Michael VanRooyen, Ronak Bhailal Patel, 'Improved Health Outcomes in Urban Slums through Infrastructure Upgrading' (2010) 71 Social Science and Medicine 935 (935-740).

${ }^{79}$ See John Bosco Isunju and others, 'Socio-economic Aspects of Improved Sanitation in Slums: A Review' (2011) 125 Public Health 369; UN HABITAT The Challenge of Slums (Earthscan Publications 2003) 11-12.

${ }^{80}$ Housing plans are usually in favour of middle and high-income earners. See C Njoku and GC Okoro 'Urban Renewal in Nigeria: Case Study of Lagos state' (2014) 3(7) Journal of Environmental and Water Science 144; Job Taiwo Gbadegesin and BT Aluko, 'The Problem of Urban Renewal for Sustainable Urban Development in Nigeria: Issues and Challenges' (2010) 7(3) Pakistan Journal of Sciences 246.

${ }^{81}$ Njoku and Okoro (n 80) 145.

${ }^{82}$ Ibid 146.

${ }^{83}$ Ocheje PJ, "'In the Public Interest": Forced Evictions, Land Rights and Human Development in Africa' (2007) 51(2) Journal of African Law 180-181.

${ }^{84} \mathrm{RA}$ Olawepo, 'Perspectives on Urban Renewal and Transportation Development in Lagos: Implications for Urban Development in Nigeria' (2010) 4(1) African Research Review 275.
} 
knit community even though they migrate from different areas for economic reasons. 85

In Abuja, the Federal Capital Territory, rapid urbanisation saw the rise in squatter settlements, especially in districts adjacent to the capital city. The housing policy was mostly in favour of high and middle-income earners as it was thought to be a more befitting image of the capital city. ${ }^{86}$ The low-income houses were located at the outskirts of the city where overcrowding and inadequate basic services was a challenge. This outlook contradicted the master plan of the city developed in 1976, which included a system of highways, infrastructure and new buildings that would wipe out surrounding farming communities, poor towns and squatter settlements. ${ }^{87}$ In a reactive response aimed at curbing this spread of informal settlements in the capital city and to uphold the master plan, the government embarked on demolition exercises in 2003 in order to rid the city of informal settlements. ${ }^{88}$ This left about 800,000 people displaced from about 49 informal settlements. ${ }^{89}$

The Center for Housing Rights and Evictions (COHRE) and the Social and Economic Rights Action Center (SERAC) COHRE and SERAC reported that the affected persons evicted usually complained of lack of or insufficient notice. $^{90}$ Though homes were usually marked prior to evictions, the residents were hardly informed of the exact date. ${ }^{91}$ Through the use of violence in carrying out these evictions, the officials denied people the opportunity to retrieve their belongings. ${ }^{92}$ These evictions left the affected persons in untold hardship as they were carried out without adequate consultation with affected persons, without due process and without providing access to legal remedies and clearly in violation of international human rights standards on evictions. The resettlement and relocation plans ${ }^{93}$ were reported not to be suitable to the affected persons as it did not adequately meet their needs especially access to source of livelihood and social services. ${ }^{94}$

In Port Harcourt, the River State capital, over one million residents of Rainbow Town were forcefully evicted in July $2000 .{ }^{95}$ This eviction carried out

\footnotetext{
${ }^{85} \mathrm{Njoku}$ and Okoro (n 80) 146.

${ }^{86}$ Erasmus Morah, 'Why Nigeria Obtained a New Capital that It Did: An Analysis of Official's Disposition in Housing Development' (1993) 59 International Review of Administrative Sciences 251.

${ }^{87}$ Keteh Amba 'The Need for Popular Participation in Abuja: A Nigerian Story of Informal Settlements' (201) 3(2) Journal of Place Management and Development 152.

${ }^{88}$ Ibid 153.

${ }^{89}$ UN-Habitat Working Paper 1 'Evictions, Acquisitions, Expropriations and Compensation: Practices and Selected Case Studies February (2013) 20.

${ }^{90} \mathrm{COHRE}$ and SERAC 'The Myth of the Abuja Master Plan' Mission Report May 2008. http://reliefweb.int/sites/reliefweb.int/files/resources/A48C369A8401D54BC 125744A003B52F5-Full_report.pdf (accessed 29 January 2017) 39.

${ }^{91}$ Ibid 42.

${ }^{92}$ Ibid 43.

${ }^{93}$ Ibid 49; UN-Habitat Working Paper (n 89) 21.

${ }^{94}$ COHRE and SERAC (n 90) 49.

${ }^{95}$ Amnesty International, 'Nigeria-Making the Destitute Homeless - FORCED evictions in Makoko, Lagos State' January 2006 AI Index - 44/001/200614 https://www.amnesty. org/download/Documents/68000/afr440012006en.pdf (assessed 2 February 2017) 15.
} 
without adequate notice, compensation or resettlement plans was carried out in the presence of armed security men whose brutality left about four persons dead and many others injured. ${ }^{96}$ In 2009, the government's desire to implement the Greater Port Harcourt Master Plan led to the demolition of buildings and other structures. ${ }^{97}$ On 28 August 2009, after a week of consultation, Njemanze waterfront community was demolished as part of the state authorities' urban renewal programme for the city. It was estimated that up to 17,000 people were forcibly evicted from their homes. ${ }^{98}$ Only a few were provided with compensation or alternative housing. ${ }^{99}$ In June 2012, despite a restraining court order, ${ }^{100}$ the government without prior notice and under the supervision of armed security forces carried out another forced eviction which affected over 10,000 people in Abommema Wharf. ${ }^{101}$ Several of those forcibly evicted had faced forced evictions in Njemanze in $2009 .{ }^{102}$ The evictions were carried out without the necessary legal and procedural safeguards including prior consultation with residents and without the provision of adequate notice, compensation or alternative accommodation and legal remedies. Residents of the demolished community including children and the elderly were left homeless and vulnerable to other human rights violations. ${ }^{103}$

In Lagos, slums have increased over the years with over 100 in Lagos alone. ${ }^{104}$ Evictions have thus been a recurrent feature of Lagos state overtime making the Lagos State government one of the worst violators of the rights of the urban poor in Nigeria. In 1990, residents of Maroko one of Nigeria's biggest slum communities with a population of over 300,000 were forcefully evicted after a 7day notice over the radio. ${ }^{105}$ Limited support was given to house owners as the resettlement project only covered 2000 out of the 10,000 house owners. ${ }^{106}$ Mass eviction of 1300 civil servants was carried out in 2005 in a bid to privatize government-owned houses which were in deplorable conditions. ${ }^{107}$ The government sold the high rise blocks of flats and promised to give possession to the buyers

\footnotetext{
${ }^{96}$ Ibid.

${ }^{97}$ Amnesty International 'Ending Forced Evictions in Law and Practice: A Thematic Submission to the United Nations Committee on Economic, Social and Cultural Rights ACT35/006/2013May 2013. https://www.amnesty.org/en/documents/act35/006/2013/en/ (accessed 26 January 2017) 6.

${ }^{98}$ Amnesty International, 'Nigeria - Forced eviction of Abonnema Wharf Waterfront: "Pack and Go"" (2012) AFR440342012 file://C:/Users/Administrator/Downloads/ afr440342012en.pdf (accessed 25 January 2017) 11.

${ }^{99}$ Ibid.

${ }^{100}$ Jim George and Others $v$ The Executive Governor of River State and others Unreported Suit No: PHC/2286/2009.

${ }^{101}$ ibid 5-7.

${ }^{102}$ ibid $11-12$.

${ }^{103}$ ibid. See also UN-HABITAT 'Evictions and Demolitions in Port Harcourt' Report of Fact Finding Mission March 2009. http://mirror.unhabitat.org/downloads/docs/10010_1_ 593998.pdf (accessed 26 January 2017).

${ }^{104} \mathrm{Njoku}$ and Okoro (n 80) 144.

${ }^{105}$ Amnesty International, 'Nigeria-Making the Destitute Homeless' (n 95) 14.

${ }^{106}$ ibid.

${ }^{107}$ UN-Habitat Evictions - Towards Solutions? (Advisory Group on Forced Evictions 2007) 71.
} 
within 90 days. The residents of the building sought a court injunction to restrain the government but this was ignored as the government proceeded to forcefully evict the tenants. ${ }^{108}$

In Makoko, one of the nine host communities of the Lagos Metropolitan and Governance Project (LMDGP), a section of the community was invaded by members of the Kick Against Indiscipline (KAI) Brigade team in April 2005 and forcibly evicted over 3000 residents by destroying their homes, properties and livelihoods. ${ }^{109}$ This eviction was carried out despite a restraining court order, without adequate notice, genuine consultation, compensation or provision of alternative accommodation. ${ }^{110}$

The forced eviction of the residents of Badia East is part of a pattern of forced evictions of people living in slums or other informal settlement around Lagos such as Maroko, Ijale Otumare, Ajeromi, Oke Ilu-Eri amongst others. The eviction in the Badia East is treated, especially in this article as there was an attempt at consultation with the victims. This eviction and process of consultation will be assessed to determine its compliance with the prescribed standards for meaningful engagement.

\section{Forced eviction in Badia East, Lagos, Nigeria}

The Badia Community is an informal settlement situated between a rail line and a swampland with a population of about 100,000 people. The residents of the community some of whom were victims of previous evictions have lived there for decades improving the area with their own resources to make it habitable. ${ }^{111}$ The community was marked as one of the beneficiaries of the World Bank Funded Lagos Metropolitan Development and Government Project, the objective of which was to ensure access to basic urban services through investment in critical infrastructure as well as urban upgrading of the community. ${ }^{112}$

On 23 February 2013, residents of Badia East Lagos had what was probably the worst nightmare of their lives as the structures that sheltered them were razed to the ground by the government bulldozers. An interview with victims of the Badia East forced eviction revealed that the residents did not receive any prior notice from the authorities. ${ }^{113}$ People's homes, business structures and other

\footnotetext{
${ }^{108}$ Ibid.

${ }^{109}$ Amnesty International 'Nigeria-Making the destitute homeless' (n 95) 8.

${ }^{110}$ Ibid 10-11.

${ }^{111}$ Amnesty International "If you love your life, move out" Forced eviction in Badia East, Lagos Nigeria' AFR/44/066/2013 https://www.amnesty.org/en/documents/AFR44/ 006/2013/en/ (accessed 28 January 2017) 11-12. This report was a joint work of the Socio-economic Rights Action Centre and Amnesty International. The SERAC promotes socio-economic rights in Nigeria through its monitoring and advocacy programs, community, legal and policy advocacy programs.

${ }^{112}$ See World Bank Lagos Metropolitan Development and Governance Project: Implementation, Completion and Results Report March 2014 http://documents. worldbank.org/curated/en/872021468290442515/pdf/ICR29680P071340IC0disclosed 04040140.pdf (accessed 2 February 2017) 2.

${ }^{113}$ Amnesty International "'If you love your life, move out' (n 111) 24.
} 
community facilities were destroyed during the demolition. Since the residents were taken by surprise, they were not given an opportunity to salvage their personal belongings. The demolition team including armed policemen intimidated residents by threatening to gun down any person who attempted to obstruct their activities. ${ }^{114}$ Amnesty International reported that on that day, at least 2,666 structures that served as homes and businesses were destroyed. This affected about 2,237 households estimated at close to 9,000 people. ${ }^{115}$ Some of the victims of the Badia East eviction have experienced such cases in previous settlements and they had to build their lives back from scratch each time. ${ }^{116}$

The Lagos State government failed to provide any relocation assistance or an alternative settlement for the affected people and they were left to suffer severe hardship as a result of being rendered homeless as well as the destruction of their source of livelihood. ${ }^{117}$ The resulting homelessness was reported to have led to the separation of families and also the death of some elderly persons affected. ${ }^{118}$ The government equally failed to put in place legal and procedural safeguards to cushion the effects of the forced eviction on the affected persons. There was absence of adequate notice, meaningful consultation, alternative housing or legal remedies or adequate compensation for the loss suffered. The Lagos State government failed to adhere to the provisions of the World Bank Policy on Involuntary Evictions in handling the problems associated with the Badia East eviction.

Given that development projects financed by international agencies within the territories of States have resulted in forced evictions, ${ }^{119}$ the World Bank Policy on Involuntary Resettlement mandates any borrower to put in place measures that are in line with the policy's direction and international human rights standards to assist victims of eviction arising from projects funded by the World Bank. The Bank has noted that involuntary resettlement due to development projects, if unmitigated, often gives rise to severe economic, social and environmental risks as production systems are dismantled; people face impoverishment due to loss of productive assets or income sources; relocation of people to environments where their productive skills may be less applicable and the competition for resources greater; weakening of community institutions and social networks amongst others. ${ }^{120}$ The World Bank resettlement policy includes safeguards to address and mitigate these impoverishment risks. ${ }^{121}$ It covers economic as well as social impacts of the Bank assisted project caused amongst others by the involuntary taking of land leading to relocation or loss of shelter, loss of assets or access to assets. ${ }^{122}$

\footnotetext{
${ }^{114}$ ibid 30.

115 ibid 5 .

116 ibid 7 .

${ }^{117}$ ibid 33 .

${ }^{118} 8_{\text {ibid } 38 .}$.

${ }^{119}$ CESCR General Comment No. 7 (n 11) para 17.

${ }^{120}$ World Bank Policy on Involuntary Resettlement para 1.

${ }^{121}$ ibid para 1 .

${ }^{122}$ ibid para 3(a).
} 
To address these impacts, the policy requires the borrower to prepare a resettlement policy framework which must ensure that displaced persons are informed about their options and rights pertaining to resettlement; consulted on and offered choices on economically feasible resettlement alternatives; provided with adequate compensation for losses directly attributable to the project. ${ }^{123}$ In doing this, the policy requires particular attention to the needs of vulnerable groups among those displaced, especially those below the poverty line, the landless, the elderly, women and children, indigenous peoples, ethnic minorities, or other displaced persons who may not be protected through national land compensation legislation. ${ }^{124}$

The policy requires meaningful consultation with displaced persons who should also be given opportunities to participate in planning and implementing resettlement programs. ${ }^{125}$ It also requires the establishment of appropriate and accessible grievance mechanisms. ${ }^{126}$ The policy also requires the borrower through meaningful consultations with affected persons and communities, local authorities, and, as appropriate, non-governmental organizations (NGOs), to determine persons who will be affected by the project and eligible for assistance. ${ }^{127}$ The persons eligible for assistance include those with legal rights to land (including customary rights) as well as those without legal right to the land they are occupying. ${ }^{128}$ The landowners are entitled to compensation for their lands as well as other necessary assistance to aid relocation. Those without legal rights are provided resettlement assistance in lieu of compensation for the land they occupy. ${ }^{129}$ The borrower is expected to prepare a resettlement plan or resettlement policy framework which covers all aspects of the proposed resettlement and represents the strategy for achieving the objectives of the policy. ${ }^{130}$ The borrower must ensure the implementation and monitoring of the resettlement plan which must be fully consistent with the policy. ${ }^{131}$ According to the policy, the resettlement plan should be developed in consultation with the people and other stakeholders even before any displacement occurs.

After the Badia East eviction, pressure from residents, NGOs working on their behalf as well as the World Bank, led the Lagos state government to put in place modalities to support the affected persons. Against this background, the Lagos state Government prepared the Resettlement Action Plan (RAP) to regulate the Badia East eviction process. Unfortunately, the RAP by the Lagos state government for the residents of Badia East was developed after the eviction had taken place and the impact weighing heavily on the affected residents. Despite the retrospective development of the plan, genuine consultation with the affected victims

\footnotetext{
${ }^{123}$ ibid para 6(a).

${ }^{124}$ ibid para 8.

125ibid para 2(b), 13(a).

${ }^{126}$ ibid para 13(a).

127ibid para 14.

${ }^{128}$ ibid para 15.

${ }^{129}$ ibid para 16.

${ }^{130}$ ibid para 18.

${ }^{131}$ ibid para 21.
} 
remains vital in order to ensure that the resettlement and compensation arrangement would be such as to mitigate the sufferings the people have experienced as a result of the eviction. ${ }^{132}$ The expected process for developing the RAP would be one that affords the affected persons the opportunity to provide input on possibilities for resettlement and compensation as well as to suggest feasible options. The next section will take a critical look at the process of consultation adopted by the Lagos state government having regard to standards set by the CESCR in its General Comment No. 7 as well as the South African Constitutional Court in the Olivia Road case on meaningful engagement with persons affected by an eviction.

\section{The flawed process of engagement with the victims of the Badia East eviction}

The Lagos State Government in July 2013, about 5 months after the eviction, issued notices on 2-3 July calling for a meeting with affected persons on the 4th of July. ${ }^{133}$ The notice practically restricted the area covered by the demolition exercise thus excluding residents of other areas not mentioned even though affected. In addition to the unreasonably short notice, the exclusion of certain areas effectively deprived some affected persons of the opportunity to participate which is an effective precondition for a meaningful engagement. It was also not in line with the World Bank policy which requires all affected persons to be captured in the RAP.

More so, there was inadequate representation of the interests affected by the Badia East eviction. For an engagement process in eviction cases to be meaningful, all potentially affected persons must be involved. In particular, the UN Basic principles requires that the 'opportunities for dialogue and consultation must be extended effectively to the full spectrum of affected persons' ${ }^{134}$ The persons affected were over 2000 but they had only eight representatives with four from Ajeromi community and four from Oke Ilu-Eri. The absence of a tenant among the representative meant that the interest of the tenants risks not being represented adequately. ${ }^{135}$ The representatives were selected from among the people who were present at the first meeting without allowing the community on its own to decide on the best persons capable of representing them. ${ }^{136}$

The Constitutional Court in Olivia Road held that meaningful engagement requires the state to effectively seek and consider the views of beneficiaries when it develops policies and programmes in the fulfilment of socio-economic rights. ${ }^{137}$

\footnotetext{
${ }^{132}$ Amnesty International, 'If you love your life, move out' (n 111) 47.

133 ibid 47.

${ }^{134}$ United Nations Basic Principles and Guidelines on Development-Based Evictions and Displacement para 39.

${ }^{135}$ Amnesty International 'At the mercy of the government: Violation of the Right to an effective remedy in Badia, East, Lagos State Nigeria' 2014 AFR/44/017/2014 https:// www.amnesty.org/download/Documents/4000/afr440172014en.pdf (accessed 3 February 2017) 13.

${ }^{136}$ ibid 13-14.

${ }^{137}$ Lilian Chenwi, 'Meaningful Engagement' in the Realisation of Socio-economic Rights: The South African Experience' (2011) 26 South African Public Law 129.
} 
Thus, it is not meaningful engagement where the government persuades the community to accept a decision it has already made on the ground that it is in their best interest. According to Amnesty international, the meeting of 4th July was attended by a large delegation of government officials who gave lengthy speeches aimed at convincing the residents to accept the government planned housing projects which included the demolitions that would follow. In all, the aim was to make them believe their sufferings were for their future benefit. Thousands of affected persons attended the meeting but only eight representatives were given a chance to speak and ask questions for two minutes each. The meeting, however, concluded without any response to the demands or questions raised by the Badia East residents. The only reference to the RAP was made by the World Bank Representative who expected the census of affected victims to be completed by 31 July 2013 and the RAP developed by 31 August 2013 . $^{138}$

On 15, 16, and 17 July 2013, the government officials conducted a verification exercise to determine those affected by the 23 February 2013 forced eviction. ${ }^{139}$ Several meetings were also held in August 2013 between the government and community representatives where it was agreed to adopt the list of affected persons compiled and submitted by the community representatives. ${ }^{140}$ The database of affected persons included 1,933 tenants and 319 structure owners. In a subsequent consultative meeting, held in September 2013, the government proposed the payment of N227, 725 each to small structure owners, N370, 740 each to medium structure owners, N449, 780 each to large structure owners, and N92, 800 each to tenants. However, many affected people considered it inadequate compensation for the losses they had suffered. The community representatives communicated people's rejection of the proposal to the government officials at a meeting on 19 September 2013 which prompted the increment of the figures to N261, 811.25 each to small structure owners, N426, 677 each to medium structure owners, N532, 769 each to large structure owners and N114, 200 to tenants. ${ }^{141}$ This RAP containing the revised compensation was signed by seven of the eight community representatives. $^{142}$ On 30 September 2013, the World Bank gave a preliminary approval to this RAP. ${ }^{143}$

However, on 20 November 2013, the government informed the people in a meeting of its decision to reduce the amounts earlier agreed upon. At the meeting, the Attorney-General told the community representatives that the Lagos state government had decided to give affected people financial assistance instead of compensation. The financial assistance included the payment of N171,725 each to small structure owners, N248,740 each to medium structure owners, N309,780 each to large structure owners, and N90,400 each to tenants. ${ }^{144}$ The reason for the

\footnotetext{
${ }^{138}$ Amnesty International, 'If you love your life, move out' (n 111) 48.

${ }^{139}$ Amnesty International, 'At the mercy of the government' (n 114) 8.

${ }^{140}$ Ibid.

${ }^{141}$ Ibid.

${ }^{142}$ Ibid 9 . The other community representative refused to sign the resolution document on the ground that the revised amount was still inadequate.

${ }^{143}$ Ibid.

${ }^{144}$ Ibid.
} 
reduction according to the government was that the affected structure owners had no land title or building permits and the amounts exceeded standard government compensation rates for people who had title to land and building permits. ${ }^{145}$

Some of the community representatives expressed their dissatisfaction with the government's offer of financial assistance, emphasising that the financial assistance was inadequate and called on the government to increase it. Despite the dissatisfaction of the community representatives, the Lagos state government sent a revised version of the September 2013 RAP titled Reviewed Resettlement Action Plan (RRAP), to the World Bank for final approval. The community representatives accepted the offer of financial assistance with conditions. The government's rejection of their conditional acceptance forced the community representatives to accept the offer unconditionally. On 27 January 2014, the World Bank approved the RRAP. ${ }^{146}$

The so-called process of consultation with the victims of the Badia East eviction was a total deviation from the actual intent of the meaningful engagement process as required by General Comment 7, the World Bank Policy and given flesh by the South African Constitutional Court in the Olivia Road case. Bad as it is, that the government altered the prior agreement unilaterally, they failed to involve the people adequately as the RAP was not disclosed to the community prior to the approval by the World Bank. ${ }^{147}$ The revised RAP was simply presented to the community for acceptance without an opportunity to have an input in the final decision considering that the final RAP contained new information. The RAP was sent by the government to the World Bank for approval even before the community representatives communicated their acceptance of the RAP. The draft of the RAP was sent to the World Bank with a letter dated 26 November 2013, over three weeks before the community representatives indicated their agreement to it through their letter dated 20 December 2013.

Muller has noted that meaningful engagement involves the forging of a partnership between the government and the people participating to enable them rise above the often misconceived conception of them has been helpless and at the mercy of government. ${ }^{148}$ The Lagos state government merely consulted with the people but made the decision unilaterally. From the RAP, it is evident the interest of the people was never taken into consideration in its development. As such, there was a top-down approach in the decision-making process. Unlike the decision in the Olivia Road case, the affected Badia East residents were reduced to a disempowered mass at the mercy of the government.

\footnotetext{
${ }^{145}$ Ibid 10.

${ }^{146}$ Ibid; Lagos State Technical Committee on Badia East 'Reviewed Resettlement Action Plan (RRAP) for Displaced Persons in Badia East' November 2013 Presented to the World Bank available at http://documents.worldbank.org/curated/en/ 622451468100139929/pdf/RP3420V50AFR0R00Box382149B00PUBLIC0.pdf (accessed 4 February 2017).

${ }^{147}$ Amnesty International, 'At the Mercy of the Government: Violation of the Right to an Effective Remedy in Badia, East, Lagos State Nigeria' 12.

${ }^{148}$ Muller (n 42) 314.
} 


\section{Observations and conclusion}

The absence of a legal right to adequate housing which carries with it the protection from forced evictions is the reason for the untold hardship that victims of evictions face in Nigeria. The provisions regarding notice and compensation as required by the Constitution as well as the Land Use Act prove very insufficient in addressing the human rights implication of forced eviction. There is equally a vacuum in the law as regards the necessary procedural safeguards for an eviction process.

Though the concept of meaningful engagement in the South African Constitutional Court was developed in the context of the existence of the substantive right to adequate housing which is absent in the Nigerian Constitution, it is a standard that can be adopted in eviction issues to address the human rights violations inherent in the process. Besides, Nigeria is a party to the ICESCR as well as many other international instruments that guarantee the right to housing which embodies the protection from forced eviction. In addition, Nigeria has not only ratified but has also domesticated the African Charter on Human and Peoples' Rights, which guarantees the right to participation in article 13. Meaningful engagement has proven itself useful in resolving disputes arising from situations in which competing interests are involved just like the Olivia Road case. It helps to curb the excesses of the higher bargaining power which is the government against the often marginalised groups affected by eviction. It balances the competing interests and ensures that to a large extent a win-win situation emerges or that the affected persons are not left worse off than they were before the eviction. In the case of Nigeria, the differing interests are the property owners, tenants and other occupiers on one hand and the government on the other hand.

A look at the aftermath of the evictions in Lagos, Abuja and Port Harcourt showed the insensitivity of the government to the plight of people affected by evictions. A common feature in all is the absence of adequate resettlement plans or even compensation making the affected persons suffer severe hardship and exposing them to further human rights violations. These issues could effectively have been addressed if there had been an opportunity for meaningful engagement between the government and the affected people prior to the eviction. Such engagement will help to discuss the timeframe for the eviction, the manner of eviction, the compensation and the adequacy of the resettlement plans. The common issue of lack of notice before an eviction would not be in issue and the usual resort to restraining court orders would be rare. Even in the case of the Badia East eviction, if there had been a proper process of engagement with the affected people in the development of the RAP, it would have helped to alleviate the difficulties the people have been subjected to after the eviction.

Unlike Nigeria, a solid foundation for meaningful engagement in South African jurisprudence is the existence of a legal basis for citizen participation in development process. The resolution of the parties in the Olivia Case is a classic example of how people's participation in issues that affect their well-being can help in resolving issues and ensuring that their needs are addressed. The Nigerian government needs to take a better approach by giving opportunity for people's participation in issues which is the hallmark of democracy. The federal and state governments must make good efforts to avoid violating the rights of the poor 
urban residents through large-scale forced evictions. Considering that forced evictions violate not only socio-economic rights but also civil and political rights which are guaranteed by the Nigerian Constitution, the government needs to put in place necessary legal framework to regulate evictions giving special attention to the important requirement of meaningfully engaging with the affected persons prior to carrying out the eviction.

\section{Disclosure statement}

No potential conflict of interest was reported by the author(s).

\section{Notes on contributors}

Aisosa Isokpan is currently a doctoral student at the Faculty of Law, University of the Western Cape, Cape Town, South Africa. She obtained her LL.M in Human Rights Protection in 2016 from the same university. She holds an LL.B degree from the University of Benin, Nigeria and she is a young promising researcher with interest in human rights protection with a number of published articles to her credit.

Ebenezer Durojaye is the project head and senior researcher at the Socio-Economic Rights Project at the Dullah Omar Institute, University of the Western Cape, Cape. He holds an LLB degree from University of Lagos, and a Master of Laws Degree (LLM) and Doctorate in Law (LLD) from University of the Free State. His areas of interest include focusing on socioeconomic rights including access to HIV/AIDS treatment, intersection between gender inequality and HIV/AIDS response in Africa, women's health and adolescents sexual and reproductive rights in Africa. He is one of the Independent Experts of the African Commission on Human and Peoples' Rights for the Committee on the Protection of the Rights of People Living with HIV (PLHIV) and those at Risk, Vulnerable to and Affected by HIV. He is currently co-editing two books- Strengthening Sexual and Reproductive Rights in Africa and Constitution Building in Africa. 